\title{
THE RATES OF SYNTHESIS AND THE TRANSPORT OF PLASMA FATTY ACID FRACTIONS IN MAN ${ }^{1}$
}

\author{
By S. R. LIPSKY, ${ }^{2}$ J. S. McGUIRE, JR., PHILIP K. BONDY, AND E. B. MAN \\ (From the Department of Internal Medicine, Yale University School of Medicine, New Haven, \\ Conn.)
}

(Submitted for publication May 6, 1955 ; accepted August 24, 1955)

Comparatively little is known regarding the metabolism of fatty acids in the plasma of man. The present investigation was undertaken in order to study the formation of fatty acids from acetate-1$\mathrm{C}^{14}$ and the relative rates at which these substances form esters with the various plasma lipid fractions under normal circumstances. In addition, an attempt was made to test in vivo the concept that fatty acids and cholesterol compete for available "acetate" which is an essential building block for both substances (1). This portion of the investigation was performed under conditions whereby the utilization of acetate for the biosynthesis of cholesterol was considerably diminished by diluting the higher precursor pool through prefeeding with large quantities of squalene (2).

\section{MATERIALS AND METHODS}

Seven patients with limited life expectancies were selected for study. All were considered to be in a good nutritional state and clinically free from metabolic disturbances. Pertinent data on these patients are listed in Table I.

The subjects were maintained on normal hospital diets during the course of the investigation. Two hundred microcuries of acetate-1- $C^{14}$ (specific activity $1.0 \mathrm{mc}$ per $\mathrm{mM}$ ) were dissolved in a convenient volume of tap water and administered orally to all patients in the postabsorptive state on the morning of the experiment. Three patients, N. D., J. G., and J. R., were fed 25 grams of "natural squalene" 8 per day in divided doses for three days prior to and two days after the administration of the radioactive compound. Serial blood samples were taken in heparinized syringes beginning one hour after the administration of acetate and continued at intervals for 48 hours. The isolation of the plasma $C^{14}$ fatty acid fractions was carried out by a slight modification of the

1 Supported in part by U. S. Public Health Service Grant A-254 (C2) of the National Institute of Arthritis and Metabolic Diseases, and the Liebmann Fund.

2 Postdoctorate Research Fellow, National Foundation for Infantile Paralysis.

${ }^{8}$ Obtained from Distillation Products Inc., Rochester, New York. methods described by Popják and Beeckmans (3) and Pihl and Bloch (4). The material designated as the fatty acids of the neutral fat of the plasma by the latter observers are those lipids which are soluble in acetone. These include the fatty acids from triglycerides, from cholesterol esters, and the free fatty acids. Since the term "neutral fat" properly refers to the triglycerides alone the expression "non-phospholipid" fatty acids will be applied to the combination of lipids which are found in the supernatant acetone. The phospholipid fatty acids, on the other hand, are those fractions precipitated from a petroleum ether solution by acetone and $\mathrm{MgCl}_{2}$.

Ten to twenty cc. of plasma was usually extracted with 250 to $500 \mathrm{cc}$. of $3: 1$ ethanol-ether and filtered. The precipitate was washed with an additional 50 to $100 \mathrm{cc}$. of the ethanol-ether mixture; the filtrate was then concentrated to 1 to $4 \mathrm{cc}$. in vacuo under nitrogen and the residue was extracted four times with 20 to $25 \mathrm{cc}$. portions of warmed petroleum ether.

During tests on the specificity of the method it was found that the volume to which the alcohol-ether extract was concentrated was a critical factor in obtaining adequate recoveries ( 90 to 100 per cent). By analyzing the lipid phosphorus content of the original filtrate and comparing it with the petroleum ether extract the following observations were made. If the quantity of residue remaining after concentration amounted to $5 \mathrm{cc}$. or more, only 50 to 75 per cent of the lipid phosphorus could be recovered in the petroleum ether system despite repeated vigorous extractions. If the residue was taken down just to dryness, complete removal from the walls of the flask was difficult, only 50 to 80 per cent of the lipid phosphorus being recovered after long periods of gentle reflexing. Since the partition coefficients of the various phospholipid fractions under these circumstances are not known, accurate control of the volume of the residue (1 to $4 \mathrm{cc}$. with 90 to 100 per cent recovery) was considered necessary to prevent fractionation and assure extraction of a representative sample of the phospholipid with petroleum ether.

After the extraction of the residue with the solvent the material was concentrated to a small volume and the phospholipid and "non-phospholipid" fatty acids were then separated by the method prescribed by Popják and Beeckmans (3). In this procedure the separation of the two fractions by repeated precipitation with five volumes of acetone and approximately 20 to 30 drops of $\mathrm{MgCl}_{2}$ in ethanol was considered complete since no detectable lipid phosphorus remained in the supernatant acetone. 
TABLE I

Clinical and laboratory data

\begin{tabular}{|c|c|c|c|c|c|c|c|c|}
\hline Patient & Age & Sex & Wilograms & Diagnosis & \multicolumn{2}{|c|}{$\begin{array}{c}\text { Plasma } \\
\text { total } \\
\text { fatty acids } \\
m E q . / L .\end{array}$} & \multicolumn{2}{|c|}{$\begin{array}{c}\text { Plasma } \\
\text { lipid } \\
\text { phosphorus } \\
\text { mg. \% }\end{array}$} \\
\hline \multicolumn{9}{|l|}{ Controls } \\
\hline $\begin{array}{l}\text { H. F. } \\
\text { J. M. } \\
\text { J. L. } \\
\text { J. R. } \\
\text { N. R. }\end{array}$ & $\begin{array}{l}35 \\
62 \\
37 \\
47 \\
59\end{array}$ & $\begin{array}{l}\mathbf{F} \\
\mathbf{M} \\
\mathbf{M} \\
\mathbf{M} \\
\mathbf{M}\end{array}$ & $\begin{array}{l}60 \\
58 \\
78.5 \\
70 \\
61\end{array}$ & $\begin{array}{l}\text { Carcinoma of breast } \\
\text { Carcinoma of tonsil } \\
\text { Oligodendroglioma } \\
\text { Carcinoma of lung } \\
\text { Carcinoma of stomach }\end{array}$ & \multicolumn{2}{|c|}{$\begin{array}{r}16.5 \\
12.9 \\
10.9 \\
8.5 \\
10.3\end{array}$} & \multicolumn{2}{|c|}{$\begin{array}{l}9.6 \\
8.2 \\
7.2 \\
5.8 \\
6.8\end{array}$} \\
\hline & & & & & \multicolumn{2}{|c|}{$\begin{array}{l}\text { Before After } \\
\text { Squalene }\end{array}$} & \multicolumn{2}{|c|}{$\begin{array}{l}\text { Before After } \\
\text { Squalene }\end{array}$} \\
\hline $\begin{array}{l}\text { Squalene-fed } \\
\text { N. D. }\end{array}$ & 25 & $\mathbf{M}$ & 55.5 & $\begin{array}{l}\text { Functioning carcinoma } \\
\text { of adrenal - removed } \\
\text { one month prior to } \\
\text { study }\end{array}$ & 10.2 & 12.2 & 6.4 & 7.8 \\
\hline $\begin{array}{l}\text { J. G. } \\
\text { J.R.* }\end{array}$ & $\begin{array}{l}63 \\
47\end{array}$ & $\begin{array}{l}\mathbf{M} \\
\mathbf{M}\end{array}$ & $\begin{array}{l}62.7 \\
70\end{array}$ & $\begin{array}{l}\text { Carcinoma of colon } \\
\text { Carcinoma of lung }\end{array}$ & $\begin{array}{r}11.0 \\
9.4\end{array}$ & $\begin{array}{l}10.1 \\
10.2\end{array}$ & $\begin{array}{l}6.1 \\
6.6\end{array}$ & $\begin{array}{l}7.0 \\
7.9\end{array}$ \\
\hline
\end{tabular}

* Patient J. R. was repeated as his own control eight weeks after first study.

The phospholipids were dissolved in 10 to $20 \mathrm{cc}$. of moist ether and saponified by the addition of an equal volume of 80 per cent ethanol and 40 per cent $(w / v)$ aqueous $\mathrm{KOH}$ at 70 to 80 degrees for 24 hours. As the saponification progressed, more and more water was added and at the end all the organic solvent was evaporated off. The soaps were transferred with hot water to separatory funnels, made acid with $\mathrm{H}_{2} \mathrm{SO}_{4}$ and the fatty acids extracted with petroleum ether.

The acetone supernatants obtained from the phospholipid precipitations were evaporated to dryness by distillation and the residues saponified with ethanolic $\mathrm{KOH}$ at 80 degrees for six hours. The unsaponifiable material was then removed by extraction with petroleum

TABLE II

Specific activity of plasma fatty acid fractions*

\begin{tabular}{|c|c|c|c|c|c|c|c|c|c|c|}
\hline \multicolumn{11}{|c|}{ Control subjects } \\
\hline Hours & $\underset{\text { NPFA }}{\mathrm{J}} \cdot \mathbf{R}$ & $\mathrm{P} \ddagger$ & $\stackrel{\text { H.F. }}{\text { NPFA }}$ & $\mathbf{P}$ & $\underset{\text { N.PFA }}{\mathrm{J}}$ & $\mathbf{P}$ & $\underset{\text { NPFA }}{\text { N. R. }}$ & $\mathbf{P}$ & NPFA & $\mathbf{P}$ \\
\hline $\begin{array}{r}\frac{1}{2} \\
1 \\
2 \\
4 \\
8 \\
10\end{array}$ & $\begin{array}{r}331 \\
1,085 \\
731 \\
468\end{array}$ & $\begin{array}{l}139 \\
287\end{array}$ & $\begin{array}{l}405 \\
858 \\
357 \\
303\end{array}$ & $\begin{array}{r}27 \\
58 \\
107\end{array}$ & $\begin{array}{r}1,190 \\
1,312 \\
943 \\
740\end{array}$ & $\begin{array}{r}8 \\
14 \\
78 \\
288\end{array}$ & $\begin{array}{l}166 \\
428 \\
537 \\
477 \\
254 \\
103\end{array}$ & $\begin{array}{r}21 \\
67 \\
69 \\
117 \\
264 \\
181\end{array}$ & $\begin{array}{r}158 \\
940 \\
1,327 \\
1,159 \\
630 \\
591\end{array}$ & $\begin{array}{r}14 \\
42 \\
41 \\
107 \\
291 \\
331\end{array}$ \\
\hline $\begin{array}{l}11 \\
12\end{array}$ & 395 & 310 & 231 & 174 & 369 & 425 & & & & 431 \\
\hline $\begin{array}{l}14 \\
14 \\
24 \\
48\end{array}$ & $\begin{array}{l}257 \\
156 \\
110\end{array}$ & $\begin{array}{r}417 \\
200 \\
98\end{array}$ & $\begin{array}{r}185 \\
153 \\
47\end{array}$ & $\begin{array}{r}277 \\
183 \\
46\end{array}$ & $\begin{array}{l}596 \\
175 \\
136\end{array}$ & $\begin{array}{l}500 \\
334 \\
150\end{array}$ & $\begin{array}{r}180 \\
99 \\
81\end{array}$ & $\begin{array}{r}202 \\
331 \\
239 \\
93\end{array}$ & $\begin{array}{l}400 \\
455 \\
282 \\
271\end{array}$ & $\begin{array}{l}451 \\
373 \\
310 \\
237\end{array}$ \\
\hline
\end{tabular}

Squalene-fed subjects

\begin{tabular}{|c|c|c|c|c|c|c|}
\hline Hours & $\underset{\mathbf{N}}{\mathrm{N}} \stackrel{\mathrm{D}}{\mathrm{F}} \dot{\mathrm{A}}$ & $\mathbf{P}$ & $\underset{\text { N.PFA }}{\mathrm{J}}$ & $\mathbf{P}$ & $\underset{\text { N. }}{\mathrm{J}} \cdot \mathbf{G} \cdot \dot{A}$ & $\mathbf{P}$ \\
\hline $\begin{array}{r}1 \\
2 \\
4 \\
8 \\
11 \\
14 \\
24 \\
48\end{array}$ & $\begin{array}{r}1,565 \\
1,700 \\
1,385 \\
864 \\
618 \\
777 \\
373 \\
205\end{array}$ & $\begin{array}{r}92 \\
100 \\
382 \\
573 \\
758 \\
759 \\
530 \\
323\end{array}$ & $\begin{array}{l}461 \\
851 \\
398 \\
309 \\
284 \\
256 \\
269 \\
165\end{array}$ & $\begin{array}{r}60 \\
81 \\
127 \\
218 \\
294 \\
368 \\
304 \\
222\end{array}$ & $\begin{array}{l}380 \\
606 \\
470 \\
194 \\
234 \\
230 \\
215 \\
144\end{array}$ & $\begin{array}{r}63 \\
102 \\
161 \\
278\end{array}$ \\
\hline
\end{tabular}

* Specific activity $=$ disintegrations per minute per mg. plasma fatty acid fraction.

$\dagger$ Non-phospholipid fatty acids.

‡ Phospholipid fatty acids. 
ether. After five extractions the solvents were evaporated off from the soaps on a water bath. The free fatty acids were obtained as described for phospholipids.

In the final step, the washed and purified fatty acids were taken up in small volumes of ether, mounted directly on lens paper in aluminum cups, $4.36 \mathrm{~cm}$.' and weighed, after the solvent was blown off, to an accuracy of $0.1 \mathrm{mg}$., according to the procedure described by Entenman, Lerner, Chaikoff, and Dauben (5).

Since the saponification and extraction procedure for the determination of the $\mathrm{C}^{14}$ content of the purified fatty acid fractions resulted in some loss of material, the total fatty acids and lipid phosphorus of plasma were determined by chemical methods previously described from this laboratory (6-11). The "non-phospholipid" fatty acids were estimated by the formula: "non-phospholipid" fatty acids $=$ total fatty acids - phospholipid fatty acids. Assuming that the average molecular weight of fatty acid to be 269 , the fatty acids of phospholipid and "non-phospholipid" fractions in $\mathrm{mEq}$. per liter are converted to milligrams per cent by multiplying by 26.9 .

\section{RESULTS}

\section{"Non-phospholipid" fatty acids}

In all of the subjects studied, the specific activity of the "non-phospholipid" fatty acids of the plasma reached a maximum value at two hours (Table II). It can be assumed on the basis of animal (12) and human (13) experiments that all available acetate-1- $\mathrm{C}^{14}$ had been completely utilized and the peak activity of expired $\mathrm{C}^{14} \mathrm{O}_{2}$ had already occurred by this time. At this point, the per cent incorporation of $\mathrm{C}^{14}$ into the "non-phospholipid" fatty acids of the total circulating plasma ranged from 0.57 to 1.91 for the control group and from 0.80 to 1.68 for the squalene-fed subjects (Table III). With the disappearance of the precursor, the synthesis of tagged fatty acids ceased and the specific activity curves began to fall rapidly during the next six to twelve hours (Figure 1). This phase probably represents the distribution of the recently formed $\mathrm{C}^{14}$ fatty acids and their utilization by the body tissues with subsequent dilution and replacement by newly synthesized non-labeled fatty acids. In five of the eight patients, a distinct secondary peak was noted 11 to 14 hours after the administration of radioactive acetate. This may be due to one of the heterogeneous components of the "non-phospholipid" fraction. Following the appearance of this peak, the specific activities of these fractions were usually lower than those of the fatty acids of phospholipids at 24 and 48 hours.

The total fatty acid and lipid phosphorus content of the plasma of all the subjects was within normal limits and was not significantly altered by the administration of squalene (Table I). The small increments noted in the lipid phosphorus after squalene feeding remain unexplained.

\section{Phospholipid fatty acids}

The specific activity of the phospholipid fatty acids was low during the first two hours of sampling (Figure 1, Table II). It continued to rise slowly and intersected the specific activity curve of the "non-phospholipid" fatty acid fraction in

TABLE III

Per cent incorporation of $C^{14}$ into plasma fatty acid fractions

\begin{tabular}{|c|c|c|c|c|c|c|}
\hline Patient & $\begin{array}{l}\text { Total fatty } \\
\text { acids of the } \\
\text { non-phospholipid } \\
\text { fraction in } \\
\text { circulating } \\
\text { plasma } \\
\text { (mg.) }\end{array}$ & $\begin{array}{c}\text { DPM*/mg. } \\
\text { NPFAt at } \\
2 \text { hours }\end{array}$ & $\begin{array}{c}\text { Per cent } \\
\text { incorporation } \\
\text { of C14 in } \\
\text { NPFA at } \\
2 \text { hours }\end{array}$ & $\begin{array}{c}\text { Total Pł in } \\
\text { circulating } \\
\text { plasma at } \\
14 \text { hours } \\
\text { (mg.) }\end{array}$ & $\begin{array}{c}\mathrm{DPM} / \mathrm{mg} . \\
\mathrm{P} \text { at } \\
14 \text { hours }\end{array}$ & $\begin{array}{l}\text { Per cent } \\
\text { incorpora- } \\
\text { tion of } \mathrm{Cls} \\
\text { in } \mathrm{P} \text { at } \\
14 \text { hours }\end{array}$ \\
\hline \multicolumn{7}{|l|}{ Controls } \\
\hline $\begin{array}{l}\text { H. F. } \\
\text { J. M. } \\
\text { J. L. } \\
\text { J. R. } \\
\text { N. R. }\end{array}$ & $\begin{array}{l}7,911 \\
5,886 \\
6,354 \\
4,316 \\
4,713\end{array}$ & $\begin{array}{r}858 \\
1,312 \\
1,327 \\
1,085 \\
537\end{array}$ & $\begin{array}{l}1.52 \\
1.75 \\
1.91 \\
1.07 \\
0.57\end{array}$ & $\begin{array}{l}4,066 \\
3,380 \\
3,991 \\
2,878 \\
2,885\end{array}$ & $\begin{array}{l}277 \\
500 \\
373 \\
417 \\
331\end{array}$ & $\begin{array}{l}0.255 \\
0.384 \\
0.338 \\
0.272 \\
0.217\end{array}$ \\
\hline \multicolumn{7}{|c|}{ Squalene-fed } \\
\hline $\begin{array}{l}\text { N. D. } \\
\text { J. G. } \\
\text { J. R. }\end{array}$ & $\begin{array}{l}4,375 \\
5,696 \\
4,756\end{array}$ & $\begin{array}{r}1,700 \\
606 \\
851\end{array}$ & $\begin{array}{l}1.68 \\
0.80 \\
0.91\end{array}$ & $\begin{array}{l}2,467 \\
2,657 \\
3,219\end{array}$ & $\begin{array}{l}759 \\
415 \\
368\end{array}$ & $\begin{array}{l}0.425 \\
0.250 \\
0.269\end{array}$ \\
\hline
\end{tabular}

* DPM = Disintegrations per minute.

$\dagger$ NPFA = Non-phospholipid fatty acids.

$\ddagger \mathrm{P}=$ Phospholipid fatty acids. 


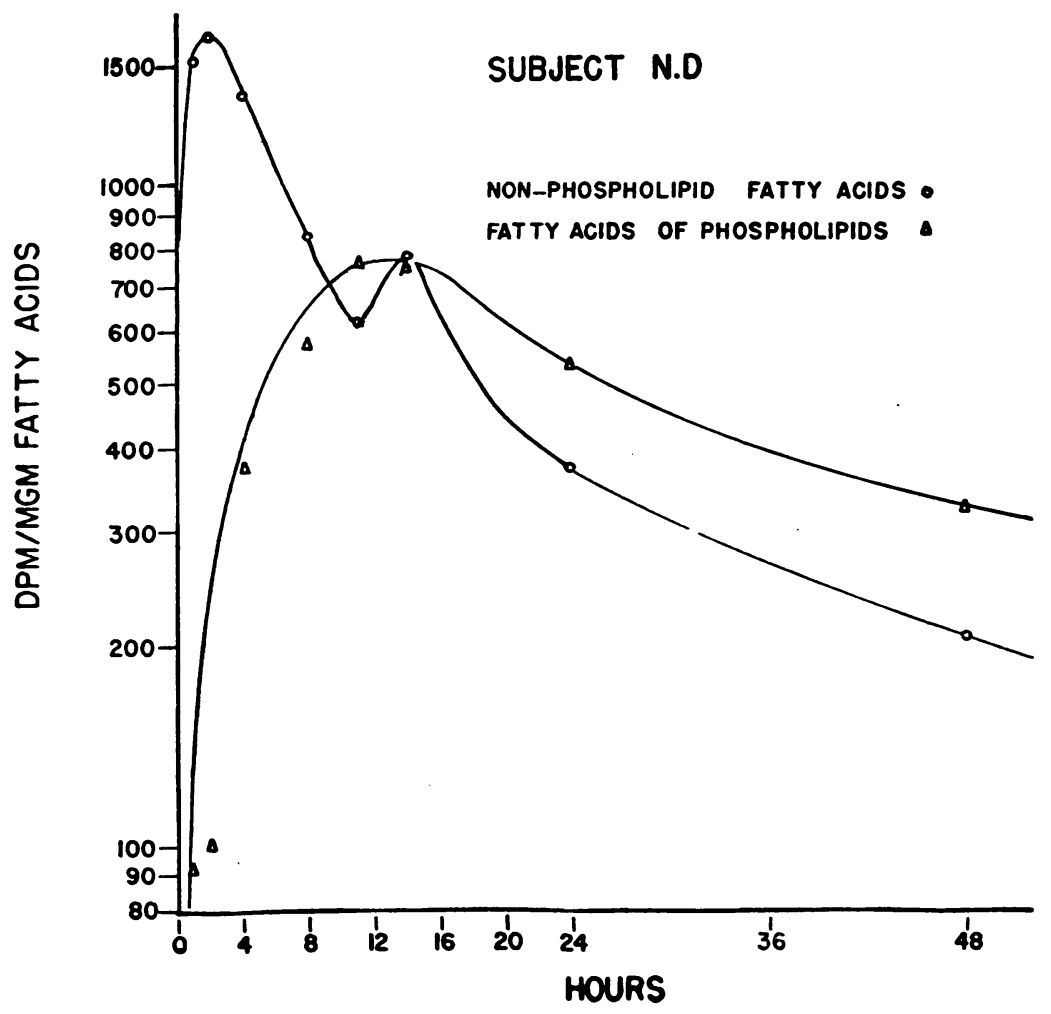

Fig. 1. The Incorporation of Acetate-1-C ${ }^{14}$ into the Fatty Acids of Phospholipids AND "Non-Phospholipids"

about 8 to 14 hours. In all the subjects except one, J. L., the specific activity reached a maximum sometime between 14 and 24 hours, and then declined at a rate at times comparable to that of the "non-phospholipid" fatty acids. At the peak (14 hours) the per cent $\mathrm{C}^{14}$ incorporated into the fatty acids of phospholipids was essentially the same for both groups of subjects, ranging from 0.217 per cent to 0.384 per cent for the controls and from 0.250 per cent to 0.425 per cent for the squalenefed patients (Table III).

\section{DISCUSSION}

The main source of energy in the body is probably derived from the breakdown of fatty acids. In the form of triglycerides these substances may be stored in fat depots and represent a readily available fuel supply. Since a large portion of utilizable carbohydrate is converted to fat prior to oxidation and an appreciable quantity of the triglyceride found in the body is derived from exogenous sources, the transportation of large quan- tities of fatty acids to and from the fat depots, presumably by way of the plasma, must occur during the metabolism of these foodstuffs. Previously, it had been assumed that the phospholipids of the plasma played a major role in the transfer of fatty acids from the liver to the tissues. However, on the basis of recent animal studies $(4,14,15)$ it would now appear that the "non-phospholipids" function as the important vehicle in this respect.

The dynamics involved in the synthesis of the plasma lipids of man are shown in Figure 1. The ascending phase of the specific activity curves for the phospholipid and "non-phospholipid" fraction is a reflection of several processes. These include the rates of formation of fatty acids from acetate, probably chiefly in the liver, the relative rates of incorporation of fatty acids into the phospholipid and "non-phospholipid" molecule, and the subsequent secretion of these substances into the plasma. The height and position of the peak of the curve in time probably represents the culmination of these events. From a comparative analysis of the curves it appears that the formation of ester link- 
ages is a much more active and rapid process for the "non-phospholipid" fatty acids than for those of the phospholipids. These findings are in accord with the results obtained in the plasma and liver slices of the rat by Pihl and Bloch (4). Similar results were noted for the dog by Harper, Neal, and Hlavacek (12). Once peak activities have been attained, the rate of utilization and storage of these compounds is roughly approximated by the slope of the descending limb of the curves. Interpretation of this slope is complicated by the fact that for both groups of substances decay is not exponential, indicating that a number of different metabolic processes contribute to the disappearance of these compounds from the blood stream. Since the lipid fractions that were isolated represent a mixture of substances this was not entirely unexpected. Thus, in the "non-phospholipids," approximately half of the fatty acids are present as the triglycerides and the other half are in cholesterol esters. Since fatty acids of the triglycerides are usually saturated they therefore are derived to a variable degree from both endogenous and exogenous sources. On the other hand, those associated with cholesterol are mostly "essential" fatty acids and are supplied by the diet. The presence of these highly unsaturated fatty acids in the "non-phospholipid" fraction would tend to dilute and lower the carbon-14 content since they are not synthesized from short chain carbon compounds to any appreciable degree by the mammalian organism.

The turnover of the "non-phospholipid" fatty acids appears to be very prompt. This, to a large extent, is probably due to the rapid exchange of fatty acids between the liver and depots via the plasma (12). In addition to this dilution by nonlabeled fatty acids, some peripheral utilization occurs. The build up and decline in the radioactivity of the fatty acids of the plasma phospholipids however is much slower. Apparently on the basis of animal investigation (12) this fraction is rapidly formed in the liver reaching peak activity in about a half an hour. However, it is only slowly released into the plasma. This observation differs from that of Zilversmit, Entenman, and Chaikoff (16) who by using P-32 noted a continuous reutilization of the tag into the phospholipid molecule over a period of several hours.
As previously implied, in this study the fatty acids consist of two groups, those which can be synthesized in the body, and those unsaturated molecules which must be derived chiefly from the diet, and therefore would not be labeled. The methods used do not discriminate between the two fractions, consequently the specific activity obtained is lower than would be anticipated if only those acids formed in the body had been studied. Since no attempt was made to control the lipid content of the diet of the patients, this could to some extent, account for the large variations in specific activity noted from patient to patient.

From the evidence that in man as in animals $(4,12,14,15)$ (a) the $C^{14}$ concentration in the fatty acids of the "non-phospholipids" of plasma builds up and declines more rapidly than that in the phospholipids and (b) the radioactivity of the phospholipids is of relatively low concentration at its peak, it is suggested that the "non-phospholipid" fraction is the important vehicle for the transport of fatty acids in the plasma. However, since the formation and degradation of the plasma phospholipids takes place chiefly in the liver (15), these substances may also function to a limited extent as carriers of fatty acids from this organ to the tissues.

In a previous communication (2) evidence was presented to show that the hydrocarbon squalene may be an intermediate in the synthesis of plasma cholesterol in man. When labeled acetate was given to human subjects prefed with squalene, the specific activity of the plasma cholesterol, although highly variable, was much less than that noted in the controls. This effect was thought to be due primarily to a dilution of the "intermediate pool" between acetate and cholesterol by the exogenous hydrocarbon. However, in this present investigation, when the plasma fatty acids of these patients were isolated and their radioactivity determined, the isotope concentrations in these fractions, although also variable, were essentially the same in the control and squalene-fed subjects. Squalene is unique among known cholesterol precursors since it alone enters the cholesterol molecule without previously breaking down to two carbon fragments (17-20).

From the results obtained, the acetate normally used for cholesterol synthesis when large quantities of squalene are administered does not ap- 
pear to contribute materially to the formation of fatty acids. However, following a dose of acetate1-C $\mathrm{C}^{14}$ approximately two to three per cent of the total radioactivity enters the plasma fatty acids and cholesterol of man. It is therefore obvious from the data presented that even if the incorporation of acetate into cholesterol was blocked completely by squalene, the increment in the fatty acid label that may have occurred could not be determined by the methods and design of this investigation.

\section{SUMMARY}

The rates of incorporation of acetate-1-C $\mathrm{C}^{14}$ into the fatty acids of the phospholipid and "nonphospholipid" fractions of the plasma of man were determined under normal circumstances. Since the formation and turnover of the fatty acids of the "non-phospholipids" was much more rapid than that of the phospholipid, it was suggested that the "non-phospholipids" may function as the major vehicle for the transport of fatty acids in the plasma.

A similar study was performed under conditions whereby the utilization of acetate for the biosynthesis of cholesterol was significantly decreased by prefeeding with large quantities of squalene. This failed to alter the incorporation of acetate into the fatty acids. The results of this phase of the investigation are discussed.

\section{REFERENCES}

1. Najjar, V. A., Clinical and biochemical features of fat metabolism: An introduction, in Fat Metabolism; A Symposium on the Clinical and Biochemical Aspects of Fat Utilization in Health and Disease, Najjar, V. A., Ed., Baltimore, The Johns Hopkins Press, 1954, p. 7.

2. McGuire, J. S., Jr., and Lipsky, S. R., The effects of squalene on the incorporation of acetate into plasma cholesterol in man. J. Clin. Invest., 1955, 34, 704.

3. Popják, G., and Beeckmans, M. L., Synthesis of cholesterol and fatty acids in foetuses and in mammary glands of pregnant rabbits. Biochem. J., 1950, 46, 547.

4. Pihl, A., and Bloch, K., The relative rates of metabolism of neutral fat and phospholipides in various tissues of the rat. J. Biol. Chem., 1950, 183, 431.

5. Entenman, C., Lerner, S. R., Chaikoff, I. L., and Dauben, W. G., Determination of carbon 14 in fatty acids by direct mount technique. Proc. Soc. Exper. Biol. \& Med., 1949, 70, 364.

6. Peters, J. P., and Man, E. B., The interrelations of serum lipids in normal persons. J. Clin. Invest., 1943, 22, 707.

7. Man, E. B., and Gildea, E. F., A modification of the Stoddard and Drury titrimetric method for the determination of the fatty acids in blood serum. J. Biol. Chem., 1932, 99, 43.

8. Man, E. B., and Gildea, E. F., Notes on the extraction and saponification of lipids from blood and blood serum. J. Biol. Chem., 1937, 122, 77.

9. Man, E. B., and Peters, J. P., Gravimetric determination of serum cholesterol adapted to the Man and Gildea fatty acid method, with a note on the estimation of lipoid phosphorus. J. Biol. Chem., 1933, $101,685$.

10. Man, E. B., A note on the stability and quantitative determination of phosphatides. J. Biol. Chem., 1937, 117, 183.

11. Sperry, W. M., Electrophotometric microdetermination of phosphorus in lipide extracts. Indust. \& Engin. Chem. (Anal. Ed.), 1942, 14, 88.

12. Harper, P. V., Jr., Neal, W. B., Jr., and Hlavacek, G. R., Lipid synthesis and transport in the dog. Metabolism, 1953, 2, 69.

13. Baker, N., Shreeve, W. W., Shipley, R. A., Incefy, G. E., and Miller, M., $C^{14}$ studies in carbohydrate metabolism. I. The oxidation of glucose in normal human subjects. J. Biol. Chem., 1954, 211, 575.

14. Bloom, B., Chaikoff, I. L., Reinhardt, W. O., and Dauben, W. G., Participation of phospholipids in lymphatic transport of absorbed fatty acids. J. Biol. Chem., 1951, 189, 261.

15. Goldman, D. S., Chaikoff, I. L., Reinhardt, W. O., Entenman, C., and Dauben, W. G., Site of formation of plasma phospholipides studied with $\mathrm{C}^{14}$ labeled palmitic acid. J. Biol. Chem., 1950, 184, 727.

16. Zilversmit, D. B., Entenman, C., and Chaikoff, I. L., The measurement of turnover of the various phospholipides in liver and plasma of the dog and its application to the mechanism of action of choline. J. Biol. Chem., 1948, 176, 193.

17. Langdon, R. G., and Bloch, K., The utilization of squalene in the biosynthesis of cholesterol. J. Biol Chem., 1953, 200, 135.

18. Zabin, I., and Bloch, K., The utilization of isovaleric acid for the synthesis of cholesterol. J. Biol. Chem., 1950, 185, 131.

19. Zabin, I., and Bloch, K., The utilization of butyric acid for synthesis of cholesterol and fatty acids. J. Biol. Chem., 1951, 192, 261.

20. Bloch, K., Clark, I. C., and Harary, I., Utilization of pranched chain acids in cholesterol synthesis. J. Biol. Chem., 1954, 211, 687. 